rh 19 Revue d'histoire du XIXe siècle

Société d'histoire de la révolution de 1848 et des

révolutions du XIXe siècle

14 | 1997

Cinquante ans de recherches sur 1848

\title{
Sur la représentation de la République en 1848 (1ère partie)
}

\section{Maurice Agulhon}

\section{OpenEdition \\ Journals}

Electronic version

URL: http://journals.openedition.org/rh19/113

DOI: $10.4000 /$ rh19.113

ISSN: $1777-5329$

\section{Publisher}

La Société de 1848

\section{Printed version}

Date of publication: 1 June 1997

ISSN: 1265-1354

\section{Electronic reference}

Maurice Agulhon, "Sur la représentation de la République en 1848 (1ère partie) », Revue d'histoire du XIXe siècle [Online], 14 | 1997, Online since 10 September 2008, connection on 21 April 2019. URL: http://journals.openedition.org/rh19/113; DOI : 10.4000/rh19.113

This text was automatically generated on 21 April 2019

Tous droits réservés 


\title{
Sur la représentation de la République en 1848 (1ère partie)
}

\author{
Maurice Agulhon
}

\section{ABSTRACTS}

About the Republic's representation in 1848 (1st part) The representation of the Republic is both a debate of opinion and a collection of images. In the shape -feminine- and in the content Republic- of these representations there is enough unity to justify a general examination. Parallel to the influence of the ideology on iconology, we have to consider the part of the image. The studies published for the "Bicentennaire" in 1989 enable us to bring a few explanations. The corpus of the official emblems begins during the revolutionary period, as shown by the example of the phrygian cap. The Republic has borrowed it from Liberty to apporopriate it. However the Republic of 1848 has abandonned the phrygian cap for a crown of sunbeams which has a more universal signification. In the same concern for political circumspections, the Republic of Cavaignac re-established the effigy of the First Consul on the legion of honour medal. The corpus of rhe city halls busts also reveals that political teachings through the settings go back to the time of the Revolution and therefore have to be studied consequently.

La représentation de la République c'est à la fois un débat d'idées et une collection d'images. Il y a dans la forme - féminine - et le contenu - République - de ces représentations assez d'unité pour justifier un examen d'ensemble. En même temps que l'influence exercée par l'idéologie sur l'iconologie, il faut prendre en compte le statut de l'image. Les travaux publiés à l'occasion du Bicentenaire en 1989 permettent d'apporter quelques précisions. Le corpus des emblèmes officiels débute par la période révolutionnaire, comme le montre le cas du bonnet phrygien. La République a emprunté celui-ci à la Liberté pour se l'approprier. Cependant la République de 1848 a délaissé le bonnet phrygien au profit d'une couronne de rayons de soleil à la signification 
plus universelle. Dans le même souci de circonspection politique, la République de Cavaignac a rétablit l'effigie du Premier Consul sur la médaille de la Légion d'honneur. Le corpus des bustes de mairie révèle lui aussi que la pédagogie politique par le décor remonte au temps de la Révolution et doit donc être étudié en conséquence.

INDEX

Mots-clés: 1848, République, Historiographie 